НАУКОВИЙ ВІСНИК

MEIBGG

ind

cientific messegger or Lviv National Universiig of
Veterinary Medicine and Biotecthologies

the

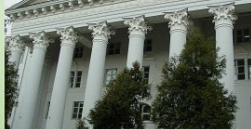

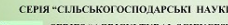

ToM 21 № 91

2019
Науковий вісник Дьвівського національного університету ветеринарної медицини та біотехнологій імені С.3. Гжицького. Серія: Сільськогосподарські науки

\author{
Scientific Messenger of Lviv National University
} of Veterinary Medicine and Biotechnologies. Series: Agricultural sciences

ISSN 2519-2698 print

https://nvlvet.com.ua/index.php/agriculture

doi: 10.32718/nvlvet-a9119

\title{
Variability of caecal parameters in rabbits
}

\author{
O. Vozna, N. Motko
}

Stepan Gzhytskyi National University of Veterinary Medicine and Biotechnologies Lviv, Ukraine

Article info

Received 20.09.2019

Received in revised form 21.10.2019

Accepted 22.10.2019

Stepan Gzhytskyi National University of Veterinary Medicine and Biotechnologies Lviv, Pekarskaya Str., 50, Lviv, 79010, Ukraine.

Tel.: +38-097-933-96-40

E-mail: biochem@lvet.edu.ua
Vozna, O., \& Motko, N. (2019). Variability of caecal parameters in rabbits. Scientific Messenger of Lviv National University of Veterinary Medicine and Biotechnologies. Series: Agricultural sciences, 21(91), 108-110. doi: 10.32718/nvlvet-a9119

Three groups of rabbits of different origin (29, 27 and 28 animals; 3 or 4-6 months of age) were slaughtered, their caecal contents analyzed and used for inoculation of in vitro cultures. Whereas the caecal $\mathrm{pH}$, dry matter percentages and acetate molar proportions in caecal volatile fatty acids (VFA) were relatively stable, molar proportions of other VFA varied considerably. In in vitro incubations, caecal parameters varied somewhat less than in vivo. Methane production varied much more than total VFA production. No non-methanogenic rabbit, however, was found. The hydrogen recovery correlated Significantly with the methane production and, in two out of three groups of rabbits, also with the propionate molar percentage. The caecal $\mathrm{pH}$ was inversely related to VFA concentration.

Key words: rabbit,caecum, metabolism, variability.

\section{Introduction}

The caecum is the major site of fibre digestion in rabbits. Caecal fermentation converts organic substrates to volatile fatty acids (VFA), gases and compounds incorporated into bacterial cells. The VFA are absorbed, providing an important source of energy for the host (Parker, 1976). The caecum is also supposed to have an important role in the etiology of digestive disturbances. Various nutritional and ontogenic factors affecting the caecal fermentation have been reviewed by Gidenne (1996). According to our knowledge, there is no study on animalto-animal variation of caecal parameters in rabbits. Agedependent variation of caecal traits in rabbits has been reported by Piattoni et al. (1995). The animal variability should by taken into account when evaluating results of in vitro experiments and various in vivo measurements. The aim of this study was to assess variability of caecal parameters in three groups of rabbits of different origin.

\section{Material and methods}

Rabbits of the first group (29 animals) were Hyla 2000 broilers from the Research Institute of Animal Production. Rabbits were fed a granulated concentrate feed containing (\%): alfalfa meal (30), wheat bran (30), barley (12), wheat meal (8), extracted soya-bean meal (8), distillers dried grains (8), rapeseed oil (1) and a vitamin- mineral supplement (3). The feed contaned $16.5 \%$ crude protein, $13.7 \%$ crude fibre and $3.5 \%$ fat.

Rabbits of the second group (27 animals) were Hyla 2000 and Hyplus broilers from a big rabbitry. Animals ware fed a granulated feed similar to the feed of the first group. No details on the feed composition were available.

Rabbits of the third group (28 animals) were crossbred rabbits purchased from small farmers. These rabbits were fed meadow hay, fodder beet and various local forages.

Rabbits of the first and second group were killed at the age of 3 months (live weight: $2.6-2.8 \mathrm{~kg}$ ). Rabbits of the third group were killed at the age of 4 -6 months (live weight: $2.6-3.0 \mathrm{~kg}$ ) Rabbits of the first group were slaughtered ca $2 \mathrm{~h}$ after the last feed intake. Other rabbits were slaughtered after ca $14 \mathrm{~h}$ fasting. The caeca were emptied by gentle squeezing and used for inoculation of in vitro cultures and analyses. The caecal contents $(25 \mathrm{~g})$ were added to $75 \mathrm{ml}$ of water or McDougall buffer (McDougall, 1948) with yeast extract (1 g/l) and urea $(0.5 \mathrm{~g} / \mathrm{l})$. To stop the fermentation in former samples, 0.1 $\mathrm{g}$ of $\mathrm{HgCl} 2$ was added immediately. The latter samples, i.e. caecal contents diluted with buffer were incubated in 0.3 I serum bottles at $39{ }^{\circ} \mathrm{C}$ for $24 \mathrm{~h}$. All bottles contained starch, pectin and wheat hemicellulose, $0.5 \mathrm{~g}$ each. The bottles were thoroughly flushed with $\mathrm{CO}_{2}$ and hermetically closed with rubber stoppers. The $\mathrm{pH}$ (ca 7.2 initially) fell to 5.8-6.0 in the course of the incubation. 
The caecal $\mathrm{pH}$ and dry matter were determined immediately. Other analyses were performed using conserved samples. Samples of the headspace gas were taken at the end of the incubation and analysed by gas-liquid chromatography ( FID) at the room temperature on a column of the Chromosorb WAW with - 15\% SP 1220 and $1 \%$ H3P04 (Supelco, USA). Total VFA were estimated by titration, after steam distillation. Their molar composition was determined employing the gas chromatograph and the same column at $140{ }^{\circ} \mathrm{C}$. Metabolic hydrogen balance was calculated according to Demeyer (1991) as: $2 \mathrm{Hrec}=100$ $(2 \mathrm{P}+2 \mathrm{~B}+4 \mathrm{M}) /(2 \mathrm{~A}+\mathrm{P}+4 \mathrm{~B})$, where $\mathrm{A}, \mathrm{P}, \mathrm{B}, \mathrm{M}$ represent molar production of acetate, propionate, butyrate and methane, respectively. Such calculation compares the amounts of metabolic hydrogen prodused and recovered in reduced end products. The statistical treatment of data was performed using the GraphPAD Software, version 1.14. One-way analysis of variance was used to evaluate differences among groups. Variability of data was ex- pressed as coefficient of variation $(\mathrm{CV})$, i.e. as percentage of standart deviation from the mean.

\section{Results and discussion}

Results are summarized in Table 1 (in vivo measurements) and Table 2 (in vitro fermentation pattern). The caecal contents of rabbits slaughtered $2 \mathrm{~h}$ after the last feed intake (group 1) had lower $\mathrm{pH}$ and higher VFA concentration and dry matter percentage than caecal contents of rabbits slaughtered after 14-16 h fasting. In fasted rabbits (groups 2 and 3), molar proportion of caecal acetate was higher and that of propionate and butyrate lower than in non-fasted rabbits. Similar finding was reported earlier by Piattoni et al. (1997). Whereas the $\mathrm{pH}$, dry matter contents and acetate percentages were relatively stable (CVs from 2.9 to 10.6\%), molar proportions of other VFA varied considerably (CVs from 15,4 to $100 \%$ ). Caecal parameters tended to be more stable in non-fasted rabbits (group 1) than in rabbits of other groups.

\section{Table 1}

Caecal $\mathrm{pH}$, volatile fatty acids (VFA) and dry matter (DM) content in rabbits

\begin{tabular}{|c|c|c|c|}
\hline \multirow{2}{*}{ Parameter } & \multicolumn{3}{|c|}{ Rabbit group } \\
\hline & 1 & 2 & 3 \\
\hline $\mathrm{pH}$ & $\begin{array}{l}5.58 \pm 0.16^{\mathrm{a}} \\
(2.9 \%)\end{array}$ & $\begin{array}{c}6.26 \pm 0.19^{b} \\
(3.0 \%)\end{array}$ & $\begin{array}{c}6.34 \pm 0.30^{c} \\
(4.7 \%)\end{array}$ \\
\hline Total VFA $(\mu \mathrm{mol} / \mathrm{ml})$ & $\begin{array}{c}101.1 \pm 20.5^{\mathrm{a}} \\
(20.3 \%)\end{array}$ & $\begin{array}{c}75.0 \pm 0.19^{b} \\
(24.9 \%)\end{array}$ & $\begin{array}{c}74.9 \pm 0.30^{\mathrm{c}} \\
(19.8 \%)\end{array}$ \\
\hline Acetate $(\%)$ & $\begin{array}{c}71.4 \pm 2.5^{\mathrm{a}} \\
(3.5 \%)\end{array}$ & $\begin{array}{c}92.1 \pm 6.2^{\mathrm{b}} \\
(6.7 \%)\end{array}$ & $\begin{array}{c}84.7 \pm 3.3^{c} \\
(3.9 \%)\end{array}$ \\
\hline Propionate (\%) & $\begin{array}{c}10.4 \pm 1.6^{\mathrm{a}} \\
(15.4 \%)\end{array}$ & $\begin{array}{c}2.7 \pm 2.4^{b} \\
(88,9 \%)\end{array}$ & $\begin{array}{c}6.0 \pm 1.8^{c} \\
(30.0 \%)\end{array}$ \\
\hline Butyrate (\%) & $\begin{array}{c}16.6 \pm 2.5^{\mathrm{a}} \\
(15.1 \%)\end{array}$ & $\begin{array}{c}3.9 \pm 3.8^{b} \\
(97.4 \%)\end{array}$ & $\begin{array}{l}7.6 \pm 2.8^{c} \\
(36.8 \%)\end{array}$ \\
\hline Other VFA (\%) & $\begin{array}{l}1.6 \pm 1.6 \\
(100 \%)\end{array}$ & $\begin{array}{r}1.3 \pm 1.2 \\
(92.3 \%)\end{array}$ & $\begin{array}{r}1.7 \pm 0.9 \\
(52.9 \%)\end{array}$ \\
\hline DM (\%) & $\begin{array}{c}23.1 \pm 1.8^{\mathrm{a}} \\
(7.8 \%)\end{array}$ & $\begin{array}{c}21.7 \pm 2.3^{\mathrm{a}} \\
(10.6 \%)\end{array}$ & $\begin{array}{c}19.4 \pm 1.5^{b} \\
(7.7 \%)\end{array}$ \\
\hline
\end{tabular}

Means \pm standard deviations. Coefficients of variation are given in parentheses.

${ }^{a b c}$ Values in the same row with different letters differ significantly $(\mathrm{P}<0.001)$.

\section{Table 2}

Production of microbial metabolites in cultures of rabbit caecal contents supplied with starch, hemicellulose and pectin

\begin{tabular}{|c|c|c|c|}
\hline \multirow{2}{*}{ Parameter } & \multicolumn{3}{|c|}{ Rabbit group } \\
\hline & 1 & 2 & 3 \\
\hline Total VFA (mmol/flask) & $\begin{array}{c}11.42 \pm 1.26 \\
(11.0 \%)\end{array}$ & $\begin{array}{c}11.44 \pm 1.25 \\
(10.9 \%)\end{array}$ & $\begin{array}{c}10.32 \pm 1.09 \\
(10.6 \%)\end{array}$ \\
\hline Acetate $(\%)$ & $\begin{array}{c}72.6 \pm 4.9^{\mathrm{a}} \\
(6.8 \%)\end{array}$ & $\begin{array}{c}64.4 \pm 3.8^{\mathrm{b}} \\
(5.9 \%)\end{array}$ & $\begin{array}{c}65.6 \pm 3.0^{\mathrm{b}} \\
(4.6 \%)\end{array}$ \\
\hline Propionate (\%) & $\begin{array}{l}8.8 \pm 1.5^{\mathrm{a}} \\
(17.1 \%)\end{array}$ & $\begin{array}{c}13.1 \pm 3.7^{\mathrm{b}} \\
(28.2 \%)\end{array}$ & $\begin{array}{c}13.0 \pm 2.4^{\mathrm{b}} \\
(18.5 \%)\end{array}$ \\
\hline Butyrate (\%) & $\begin{array}{c}17.0 \pm 3.7^{\mathrm{a}} \\
(21.8 \%)\end{array}$ & $\begin{array}{r}20.1 \pm 2.8^{\mathrm{b}} \\
(13.9 \%)\end{array}$ & $\begin{array}{c}19.0 \pm 3.2^{\mathrm{ab}} \\
(16.8 \%)\end{array}$ \\
\hline Other VFA (\%) & $\begin{array}{c}1.6 \pm 1.6 \\
(100 \%)\end{array}$ & $\begin{array}{c}2.4 \pm 1.1 \\
(4.6 \%)\end{array}$ & $\begin{array}{r}2.4 \pm 0.9 \\
(37.5 \%)\end{array}$ \\
\hline Methane ( $\mu \mathrm{mol} /$ flask) & $\begin{array}{c}952 \pm 338 \\
(35.5 \%)\end{array}$ & $\begin{array}{c}1027 \pm 507 \\
(49.4 \%)\end{array}$ & $\begin{array}{c}813 \pm 555 \\
(68.3 \%)\end{array}$ \\
\hline $2 \mathrm{H}$ recovery $(\%)$ & $\begin{array}{c}37.1 \pm 6.5^{\mathrm{a}} \\
(17.5 \%)\end{array}$ & $\begin{array}{c}45.8 \pm 10.4^{\mathrm{b}} \\
(22.7 \%)\end{array}$ & $\begin{array}{c}42.5 \pm 10.1^{\mathrm{ab}} \\
(23.8 \%)\end{array}$ \\
\hline
\end{tabular}

Means \pm standard deviations. Coefficients of variation are given in parentheses.

abc Values in the same row with different letters differ significantly $(\mathrm{P}<0.001)$ 
In in vitro experiments, caecal parameters varied somewhat less than in vivo. Methane production varied more than VFA production (CVs $35.5-68.3 \%$ and $10.6-$ $11.0 \%$, respectively). No non-methanogenic rabbit among 84 animals was found. Piattoni et al. (1997) observed that in in vitro incubations the effect of fasting was not pronounced when substrate was added to cultures. In this study, caecal microbes from non-fasted rabbits (group 1) produced significantly more acetate and less propionate than caecal microorganisms of fasted rabbits (groups 2 and 3). It should be, however, taken into account that diets were not the same in the three groups.

Statistical analysis revealed that the $2 \mathrm{H}$ recovery correlated significantly $(\mathrm{P}<0.01)$ with the methane production. Correlation coefficients were $0.78,0.68$ and 0.96 in the group 1, 2 and 3, respectively. In groups 1 and 3, the $2 \mathrm{H}$ recovery correlated also with the propionate percentage (correlation coefficients, 0.46 and 045 , respectively). The caecal $\mathrm{pH}$ and VFA concentration values were inversely related Correlation coefficients were $-0.61,-0.46$ and -0.10 in groups 1,2 and 3, respectively. The latter coefficient was not statistically significant. Similar relationship between pH and VFA observed Jensen (1977) in the rumen fluid and Piattoni et al. (1995) in rabbit caecal conttents. No significant correlation between production of methane and that of other metabolites was found. In the rumen, an inverse relationship between production of methane and propionate exists (Van Nevel et al., 1974).

\section{Conclusions}

Article is dedicated to research of peculiarities of microbial metabolism in caecum of rabbits of different nutrients, especially carbohydrates, in connection with age and action of many exogenous factors, which have goaldirected influence on common metabolism in growth organism, anabolic processes are intensified and the productivity of animals is increased.

It was determined, that microbial metabolism in caecum is at higt level and it basic peculiarities is increased production of volatile fatty acids (VFA), the content of acetate $\left(\mathrm{C}_{2}\right)$ of which consists of $80 \mathrm{~mol} \%$, propionate $\left(\mathrm{C}_{3}\right)$ is formed not enough $(<5 \mathrm{~mol} \%)$. The intensity of metabolism and the correlation of last products of enzyme depends on the age of rabbits. Methanogenese begins its functioning from 8 -week of age. Thanks to transition on plant feeds, the production of $\mathrm{C}_{2}$ is increased and forming of $\mathrm{C}_{3}$ is decreased twice.
Not only scientific and cognitive information on quantitative evaluation of end products of microbial fermentation in the caecum is important for regulating metabolism in the direction of enhancing nutrient assimilation and improving the productive features of rabbits, but also knowledge about the individual molar redistribution of low-molecular-weight carboxylic acids derived from carbohydrates and other sources of carbon, nitrogen and energy under certain conditions of nutrition.

\section{References}

Demeyer, C I. (1991). Quantitative aspects of microbial metabolism in the rumen and hindgut. In Rumen Microbial Metabolism and Ruminant Digestion, Jouany, J. P. (ed). INRA Editions, Paris, 217-237. https://www.scirp.org/(S(i43dyn45teexjx455qlt3d2q))/ref erence/ReferencesPapers.aspx?ReferenceID=1594020.

Gidenne, T. (1996). Nutritional and ontogenic factors affecting rabbit caeco-colic digestive physiology. In Proc $6^{\text {th }}$ World Rabbit Congress, 1, 16-28. https://world-rabbit-science.com/WRSA-

Proceedings/Congress-1996-Toulouse/Papers-pdf/01Nutrition/01-GIDENNE.pdf.

Jensen, K. (1977). Fermentation pattern in the bovine rumen after feeding straight feeds. Acta Vet. Scand, $18,98-107$.

McDougall, E.I. (1948). Studies on ruminant saliva I. The composition and output of sheep's saliva. Blochem. J., 43, 99-106. https://www.ncbi.nlm.nih.gov/pmc/articles/ PMC1274641.

Parker, D.S. (1976). The measurement of production rates of volatile fatty acids in the caecum of the conscious rabbit. Br. J. Nutr., 36(1), 61-70. doi: 10.1079/BJN19760058.

Piattoni, F., Demeyer, D., \& Maertens, L. (1997). Fasting effects on in vitro fermentation pattern of rabbit caecal contents. Wld Rabbit Sci., 5(1), 23-26. doi: 10.4995/wrs.1997.314.

Piattoni, F., Maertens, L., \& Demeyer, D. (1995). Age dependent variation of caecal contents composition of young rabbits. Arch. Anim. Nutr., 48(4), 347-355. doi: 10.1080/17450399509381854.

Van Nevel, C.J., Prins, R.A., \& Demeyer, D.I. (1974). On the inverse relationship between methane and propionate in the rumen. Z. Tierphysiol. Tierernahrg. u. Futtermittelkde 33(3), 121-125. https://www.ncbi.nlm. nih.gov/pubmed/4471670. 